\title{
APRESENTAÇÃO - SUJEITOS EM TRÂNSITO: VIAGENS E VIAJANTES NA HISTORIOGRAFIA DA EDUCAÇÃOO
}

A problemática das viagens e dos viajantes tem sido mote de muitas pesquisas, resultando em teses, dissertações, eventos e publicações diversas sobre a temática, evidenciando a diversidade de olhares, caminhos e abordagens. Assim, todas as viagens são educativas? Como a temática vem sendo trabalhada pela historiografia da educação? Com quais fontes e caminhos metodológicos? Quem são os sujeitos que viajam?

A circulação das ideias, as "novidades" pedagógicas e o intercâmbio podem ser apontados como motivações para as muitas andanças realizadas por sujeitos preocupados com a educação lato sensu. Assim, o livro "Viagens Pedagógicas" (2007), organizado pelos professores Ana Chrystina Mignot e José Gonçalves Gondra reúne uma série de experiências de viagens de educadores e educadoras, num mosaico com diferentes nacionalidades, temporalidades e destinos que ajuda a visualizar os diferentes esforços e pesquisas preocupadas com a historicidade e importância das viagens para se compreender os processos educativos. O livro é composto por trabalhos que ajudam a dimensionar o interesse pela temática no âmbito da história da educação e a diversidade de fontes. No ano de 2015, o livro "Mulheres em trânsito: intercâmbios, formação docente, circulação de saberes e práticas pedagógicas”, organizado por Alexandra Lima da Silva, Evelyn de Almeida Orlando e Maria José Dantas, procurou dar visibilidade aos diferentes significados das viagens realizadas por mulheres, com destaque para as viagens de educadoras.

Por sua vez, outra importante publicação na área sobre a temática é o dossiê "Viagens de educadores, circulação e produção de modelos pedagógicos”, que compõe a Revista Brasileira de História da Educação (2010). Os textos do dossiê foram apresentados no VII Congresso Luso- 
Brasileiro de História da Educação, realizado no ano de 2007. Destaco ainda, o livro "Exílios e viagens: ideários de liberdade e discursos educativos. Portugal e Espanha, séc. XVIII-XX”, organizado por Margarida Felgueiras e Antón Costa Rico.

Dentre a recente produção acadêmica no âmbito da história da educação, destaco a crescente produção de teses e dissertações que exploram a viagem em suas diferentes possibilidades de análise. O trabalho de Jussara Pimenta fez uso de cartas e crônicas publicadas em jornais como fonte de pesquisa para estudar a viagem de Cecília Meireles a Portugal em 1934 (PIMENTA, 2008). Diários e o relatório de viagem foram as fontes privilegiadas por Silmara Cardoso (2011), para analisar o ideário educacional brasileiro do intelectual Anísio Teixeira. A tese de Inára Garcia Pinto (2011) também parte de um relatório para compreender os significados da viagem do professor primário Luiz Augusto dos Reis que, em 1891, a Portugal, Espanha, França e Bélgica. A tese de Alexandra Lima da Silva analisou a viagem de Rocha Pombo aos estados do norte do Brasil como uma estratégia de legitimação do autor no campo intelectual (SILVA, 2012). Já a tese de Sara Raphaela Amorim explorou a viagem como missão em Nestor dos Santos Lima (AMORIM, 2017).

Este dossiê procura dar visibilidade a estudos sobre a temática viagens e viajantes na historiografia da educação, em pesquisadoras e pesquisadores situados em diferentes instituições brasileiras, como também, em países como México, Espanha e Portugal.

Elizabeth Silva explora as viagens de Nísia Floresta pelo Brasil afora, no texto intitulado "As viagens de Nísia Floresta pelo solo brasileiro durante o século XIX”. Por seu turno, Helder Henriques e Amélia de Jesus Marchão discutem a importância da circulação de ideias através das viagens pedagógicas ancorados no exemplo da Universidade de Coimbra, no artigo "Uma perspetiva sobre Alves dos Santos (1866-1924): apropriação e difusão de ideias pedagógicas em Portugal”. A professora Blanca Susava Veja Martínez explora os relatos de viagem de três professoras rurais mexicanas que transitaram dentro do nordeste do país para fundar escolas e levar a diante sua prática de ensino, no artigo "Relatos de viajes: maestras, escuelas y caminos rurales em el México del siglo XX”. 
Em "Uma viagem, um engenheiro, uma escola: reorganização da escola prática de aprendizes da Estrada de Ferro Central do Brasil (1905)", Adriana Valentim Beaklini analisa a reorganização do curso profissional da Escola Prática de Aprendizes da Estrada de Ferro Central do Brasil, no bairro do Engenho de Dentro, no Rio de Janeiro, a partir das impressões da viagem aos Estados Unidos, realizada pelo subdiretor da Seção Locomoção, o engenheiro José Joaquim da Silva Freire, em 1905

O artigo "Onde os laços se atam: sociabilidade e política nos relatórios das viagens pedagógicas do intelectual norte-rio-grandense Nestor dos Santos Lima (1913-1923)", de Sara Raphaela Machado de Amorim, explora as viagens comissionadas de Netos Lima, que se lançou a conhecer o ensino nos centros de maior desenvolvimento educacional do Brasil, Argentina e Uruguai. Já as viagens de Anttonieta de Souza ao Egito, na década de 1950, foram o foco do artigo de Ednardo Monteiro Gonzaga do Monti, intitulado "Música da terra dos faraós: aprendizagens de Anttonieta de Souza numa viagem ao Egito". Por fim, as incursões e trabalhos pastorais de Frei Betto nos países do socialismo real especialmente Cuba, Nicarágua, União Soviética e as reflexões que ele faz entre convergências e divergências da teoria marxista e a religião cristã foram analisadas no artigo "Frei Betto em experiências de viagens: o cristão no socialismo real”, de Rhaissa Marques Botelho Lobo.

As viagens e os viajantes permitem diferentes abordagens e olhares. Nesses termos, o presente dossiê procura contribuir para o debate em torno deste importante e intrigante tema.

Prof. ${ }^{a}$ Dr. ${ }^{a}$ Alexandra Lima da Silva Universidade do Estado do Rio de Janeiro, Brasil Organizadora do dossiê temático 


\section{Referências}

AMORIM, S. R. M. Viagem como missão: intercâmbio pedagógico do educador Nestor dos Santos Lima (1913-1923). Tese (Doutorado em Educação), Universidade do Estado do Rio de Janeiro, 2017.

CARDOSO, S. Viajar é ser autor de muitas histórias? Experiências de formação e narrativas educacionais de professores brasileiros em viagem aos Estados Unidos (1929-1935). São Paulo: Tese (Doutorado em Educação), Universidade de São Paulo, 2015.

MIGNOT, A. C.; GONDRA, J. (org.). Viagens pedagógicas. São Paulo: Cortez, 2007.

PIMENTA, J. As duas margens do Atlântico: um projeto de integração entre dois povos na viagem de Cecília Meireles (1934). Tese (Doutorado em Educação), Universidade do Estado do Rio de Janeiro, 2008.

PINTO, I. Um professor em dois mundos: a viagem do professor Luiz Augusto dos Reis à Europa (1891). Tese (Doutorado em Educação), Universidade de São Paulo, 2011.

SILVA, A. L.; ORLANDO, E. A.; DANTAS, M. J. (org.). Mulheres em trânsito: intercâmbios, formação docente, circulação de saberes e práticas pedagógicas. Curitiba: CRV, 2015. 